\title{
Modification of the roof bolt support technology in the conditions of increasing coal mining intensity
}

\author{
Oleksandr Krukovskyi ${ }^{1,}$, Yurii Bulich ${ }^{1}$, and Yuliia Zemlianaia $^{1}$ \\ ${ }^{1}$ Institute of Geotechnical Mechanics named by N. Poljakov of National Academy of Sciences of \\ Ukraine, 49005, Dnipro, Simferopolska Str., 2a, Ukraine
}

\begin{abstract}
The modification of the technology roof bolt supporting of mine workings in the conditions of increasing the coal mining intensity has been made. The technological schemes have been developed for the phased construction of roof bolting and frame support. This schemes make it possible to temporarily postpone the setting of frames in the mine working face, reduce the time and labour intensity for covering with a grid of the mine working arch and setting the bolts, as well as to increase the safety. The analysis of changes in the stress state of the border massif during the phased construction of roof bolting and frame support has been made. It is shown that the technology of phased construction of roof bolting and frame support ensures the maintaining a stable state of host rocks. In addition, the time between the extraction of the coal-rock mass and the setting of the primary support, as well as the distance between the face and the first row of roof bolts has been reduced to a minimum. The suggested approach makes possible to ensure the rate of preparatory mine workings development that are necessary for the intensification coal mining.
\end{abstract}

\section{Introduction}

At the present time, the combined roof bolt and frame supporting of mine workings is actively used in the coal mines of Ukraine in a wide range of geological conditions with almost no restrictions by the type, purpose, lifespan, section and location of mine workings in the rock massif [1-4]. As was illustrated by practical experience, despite the advantages, this type of supporting also has disadvantages. The high concentration of works in the mine working face constrains the rate of development $[5,6]$, complicates the implementation of technological operations and leads to the technology violation and work safety. For example, in the mine working face, the arch support frames are set first, the grid is being hanged, but the roof bolts are to be installed with significant delays. All this violates the principles of bearing roof bolt supporting, reduces the work safety and the effectiveness of modern resin-grouted roof bolts application and the supporting as a whole [7, 8]. The importance of time of setting the supporting elements after the face recedes is also shown in the works $[9,10]$. The process of mine workings performance in time and changing the

*Corresponding author: igtm@ukr.net 
mechanical properties of the computational system in the work [10] is modelled with the use of initial stresses procedure. Therewith, it is shown that the sequence of mining operations has a significant influence on the stress values in the support elements at the completion of the mine working development.

To ensure the intensification of mining operations, the existing technologies of the combined roof bolt and frame supporting should be improved in a such way, in order to reduce the concentration of works in mine working face, to make the primary roof bolts setting in the mine working face more convenient without violating the safety rules. Therefore, the purpose of the work is to develop the technological schemes for the phased construction of bearing and roof bolt supporting of mine workings.

\section{Development of technological schemes for the phased construction of bearing and roof bolt supporting}

The technology of construction of roof bolt and frame supporting consists of a number of technological operations. It is known from the practical experience that the most timeconsuming and long-term of them are the setting of arch support and bolting-up. These operations are performed in the mine working face, which complicates their implementation. Therefore, in order to increase the rate of mining operations, it is proposed to divide in time the process of roof bolting and frame construction in the mine working face into several stages:

- setting the primary scheme for the roof bolt supporting (Fig. 1);

- intermediate strengthening of support (Fig. 2) with side roof bolts and, in some cases, with frames;

- supplementing of the intermediate scheme of the roof bolting and frame support to the full one (Fig. 3).

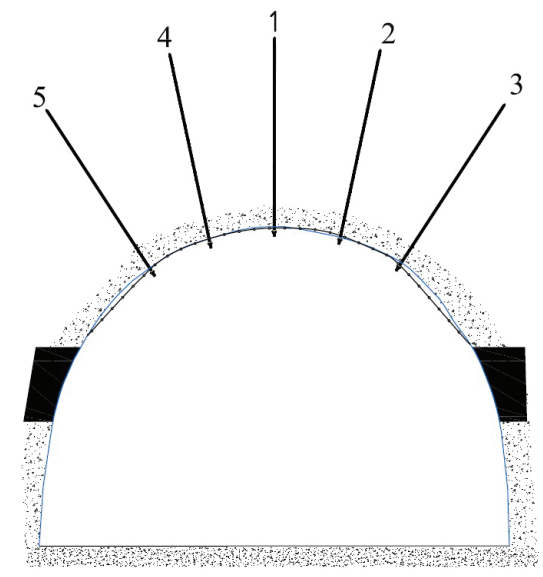

Fig. 1. An example of the primary scheme for the roof bolt supporting.

The primary scheme for the roof bolt supporting consists of the minimum required number of roof bolts and is calculated based on the conditions of maintaining a stable state of mine working for a period of time until the subsequent support strengthening. The place and time of setting - in the mine working face, immediately after face advance. The roof bolts 1-5, set with an inclination to a face, in addition to the advance supporting, have the functions of temporary support in the area adjacent to the face.

The intermediate strengthening of support consists of additional roof bolts (roof bolts 6 and 7 in Figure 2) and frames and is calculated based on the conditions of maintaining a 
stable state of mine working for an additional period of time prior to the construction of a complete supporting scheme. The place and time of setting the elements of the schemes for intermediate strengthening of support is $10-30 \mathrm{~m}$ from the mine working face. In most cases - behind the mining machine. Thus, the rocks extraction by a mining machine is partially combined in time with the construction of support.

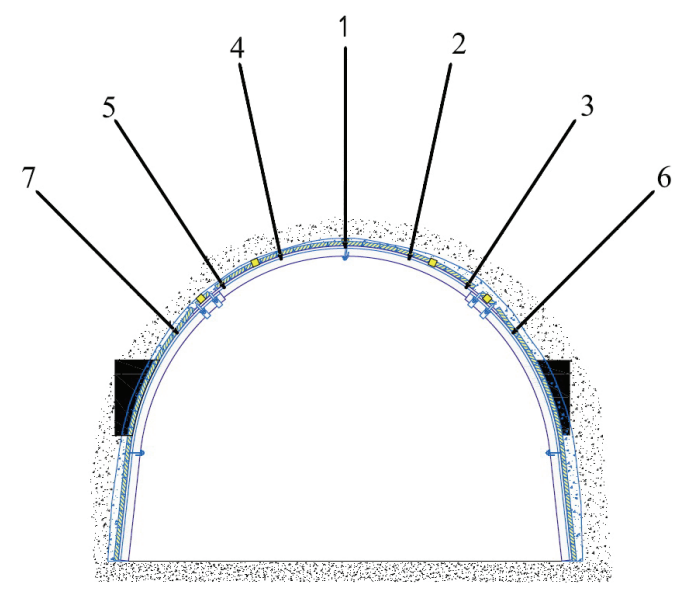

Fig. 2. An example of a scheme for the intermediate strengthening of the roof bolting and frame supporting.

The bolts B1-B4 (Fig. 3) strengthen the sides of mine working under the stratum and supplement the already constructed support elements to the complete scheme, which ensures a stable state of mine working for the whole period of its operation.

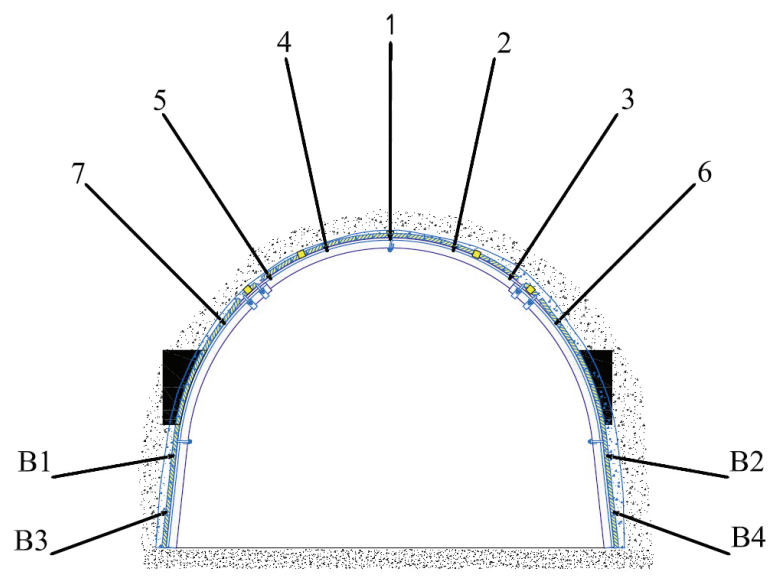

Fig. 3. An example of the complete scheme for roof bolting and frame supporting.

The frame support is being set if it has not been installed at the previous stage. The place and time of setting 50-100 $\mathrm{m}$ from the mine working face, or more, depending on the stability of the mine working sides and the value of its bottom swelling.

In order to ensure the stability of the mine working face, when using the developed phased technological schemes of supporting for the period of unproductive time, for example during on-shift repair work, it is planned to strengthen the primary scheme by increasing the number of roof bolts. 


\section{Methods}

A study of changes in the stresses field during the staged construction of the elements of the roof bolting and frame supporting is performed by means of computational simulation [11]. The unsteady stress state of the rock massif in the vicinity of mine workings is described by a system of equations [12]:

$$
c_{g} \frac{\partial u_{i}}{\partial t}=\sigma_{i j, j}+X_{i}(t)
$$

where $c_{g}$ - the damping coefficient, $\mathrm{kg} /\left(\mathrm{m}^{3} \mathrm{~s}\right) ; u_{i}$ - the displacements, $\mathrm{m} ; \sigma_{i j, j}-$ the derivatives of the stress tensor components along $x, y, \mathrm{~Pa} / \mathrm{m} ; X_{i}(t)$ - the projections of the external forces acting on the volume unit of a solid body, $\mathrm{N} / \mathrm{m}^{3}$.

The problem is solved in an elastic-plastic formulation. For the mathematical description of the process of rocks changeover into a disturbed state, the Mohr-Coulomb failure theory is applied. The initial and boundary conditions for the task are set to the following:

$$
\begin{gathered}
\left.\sigma_{y y}\right|_{t=0}=\gamma H ;\left.\quad \sigma_{x x}\right|_{t=0}=\lambda \gamma H ;\left.\quad u_{x}\right|_{t=0}=0 ;\left.\quad u_{y}\right|_{t=0}=0 ; \\
\left.u_{x}\right|_{\Omega_{1}}=0 ;\left.\quad u_{y}\right|_{\Omega_{2}}=0 ;
\end{gathered}
$$

where $\lambda$ - the side thrust coefficient; $H$ - the mining depth, $\mathrm{m} ; \gamma$ - the averaged weight of the overlying mine rocks, $\mathrm{N} / \mathrm{m}^{3} ; \Omega_{1}$ - the vertical boundaries of the outer contour; $\Omega_{2}-$ the horizontal boundaries of the outer contour.

The problem is solved by using the finite element method $[11,13,14]$.

To assess the stresses field, the following parameters were used:

- $Q=\left(\sigma_{1}-\sigma_{3}\right) / \gamma H$ characterizes the diversity of the stress field components $\left(\sigma_{1}, \sigma_{3}-\right.$ maximum and minimum components of the principal stress tensor);

- $S_{\max }=\sigma_{1} / \gamma H$ characterizes the diversity of the maximum component stress field.

The mine working with cross-section $15.1 \mathrm{~m}^{2}$ is analysed given the typical for Western Donbas mining and geological conditions with a heterogeneous composition of host rocks. In the roof of mine working at a distance exceeding the zone of roof bolting, there is a coal interlayer. The properties of rocks are represented in Table 1.

Table 1. Mechanical properties of rock.

\begin{tabular}{|l|c|c|c|c|c|c|}
\hline Rock & $\begin{array}{c}\text { Thickness, } \\
\mathrm{m}\end{array}$ & $\begin{array}{c}\text { Axial } \\
\text { compressive } \\
\text { strength, } \sigma_{\mathrm{c}}, \\
\mathrm{MPa}\end{array}$ & $\begin{array}{c}\text { Deformation } \\
\text { modulus, } E, \\
\mathrm{MPa}\end{array}$ & $\begin{array}{c}\text { Poisson's } \\
\text { ratio of } \\
\text { rock mass }\end{array}$ & $\begin{array}{c}\text { Cohesion, } \\
C, \mathrm{MPa}\end{array}$ & $\begin{array}{c}\text { Friction } \\
\text { angle, deg }\end{array}$ \\
\hline Sandstone & 2 & 46 & $2.1 \cdot 10^{4}$ & 0.36 & 11.9 & 35.0 \\
\hline Siltstone & 3 & 27 & $1.2 \cdot 10^{4}$ & 0.31 & 7.8 & 30.0 \\
\hline Coal & 0.2 & 31 & $0.3 \cdot 10^{4}$ & 0.25 & 8.8 & 30.5 \\
\hline Siltstone & 5.6 & 27 & $1.2 \cdot 10^{4}$ & 0.31 & 7.8 & 30.0 \\
\hline Coal & 1.1 & 31 & $0.3 \cdot 10^{4}$ & 0.25 & 8.8 & 32.5 \\
\hline Argillite & 9 & 25 & $1.1 \cdot 10^{4}$ & 0.32 & 7.4 & 28.5 \\
\hline
\end{tabular}

The depth of mine working development $400 \mathrm{~m}$. The thickness of the coal seam $1.1 \mathrm{~m}$. The roof bolt length $2.4 \mathrm{~m}$. 


\section{Results and discussion}

The initial distribution of the stresses field parameters and inelastic deformation zone prior to the support setting are shown in Figures 4, 5.
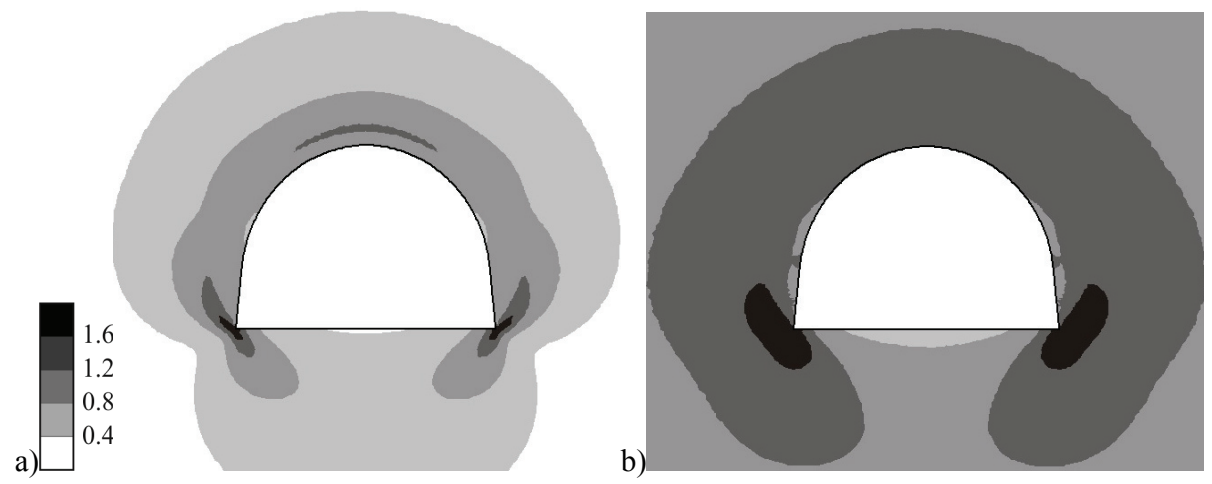

Fig. 4. The distribution of the geomechanical parameters values in the border rocks prior to the support setting: $\mathrm{a}-Q ; \mathrm{b}-S_{\max }$.

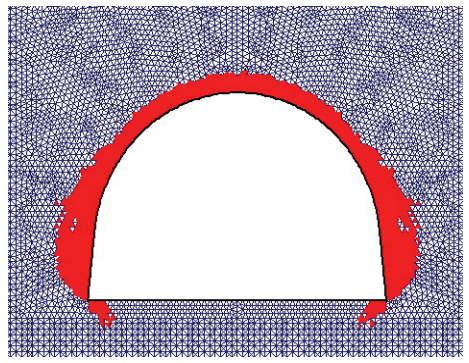

Fig. 5. The zone of inelastic deformations prior to the support setting.

In the virgin massif, outside the zone of mine working influence, the mine rocks are in the conditions of triaxial compression. The vertical component of the stresses field is determined by the weight of the overlying stratum of mine rocks, and the two horizontal components - by the side thrust of rocks. Since the side thrust coefficients are close to unity, the state of mine rocks in natural occurrence is close to uniform compression. The difference between the principal stresses components in the virgin massif is usually close to zero. During the development of mine working, the stresses field within the zone of its influence is changed. The minimum component tends to zero, and the maximum component increases (Fig. 4). Near the face, the dimensions of the inelastic deformation zone are insignificant, its depth does not exceed 0.3-0.5 m (Fig. 5).

Let us study the redistribution of parameters of the stresses field and inelastic deformation zone at the first stage of the support construction, Figures 6, 7. Immediately after the regular next rock extraction, according to the primary scheme, the main roof bolts with an inclination to the face are set into the mine working roof (roof bolts 1-5 in Figure 1).

The main roof bolts, in addition to the advance leading supporting, perform the function of temporary support in the area adjacent to the face. The bearing armoured-rock beam (Fig. 6a) is formed in the mine working roof, which contributes to the rock strengthening, prevents their possible stratification and the collapse of potentially dangerous rock blocks. For a certain period of time, the increase in the zone of inelastic deformations is blocked (Fig. 7). 
a)

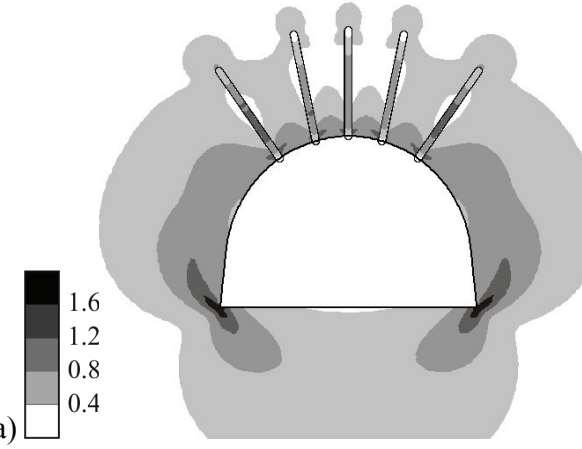

b)

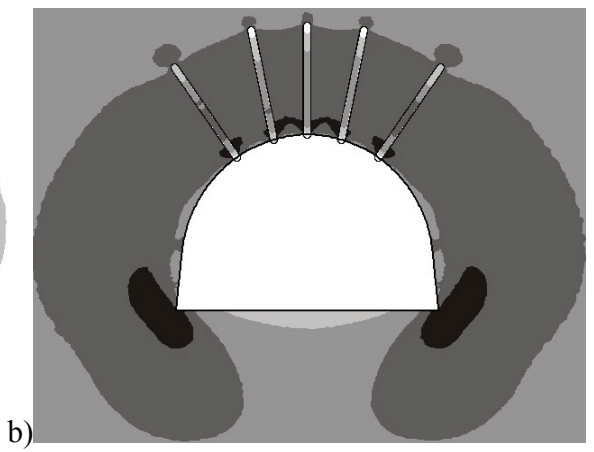

Fig. 6. The distribution of the geomechanical parameters values in the border rocks and roof bolts, the primary scheme of the support setting: $\mathrm{a}-Q ; \mathrm{b}-S_{\max }$.

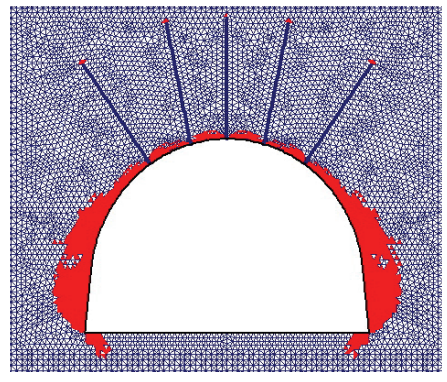

Fig. 7. The zone of inelastic deformations, the primary scheme of the support setting.

In the soft rocks, the roof bolting and rock overlapping formed in the roof, works as a rigid inclusion. When the face recedes, the loads in the roof and sides of mine working increase. To maintain the overlapping in a stable state, it is necessary to distribute the load on the mine working sides. For this purpose, at the second stage of the support construction, the additional roof bolts (roof bolts 6, 7 in Figure 2) are being set and, if it is necessary, the frames are set. The horizontal projections of the additional roof bolts should extend beyond the line of the mine working sides of not less than $1 \mathrm{~m}$. The specific schemes of strengthening are calculated based on the conditions of maintaining a stable state of mine working for an additional period of time prior to the construction of complete schemes of roof bolting and frame supporting. The distribution of parameters of the stresses field and inelastic deformation zone with an additional setting of one roof bolt in the upper part of mine working sides is shown in Figures 8, 9.
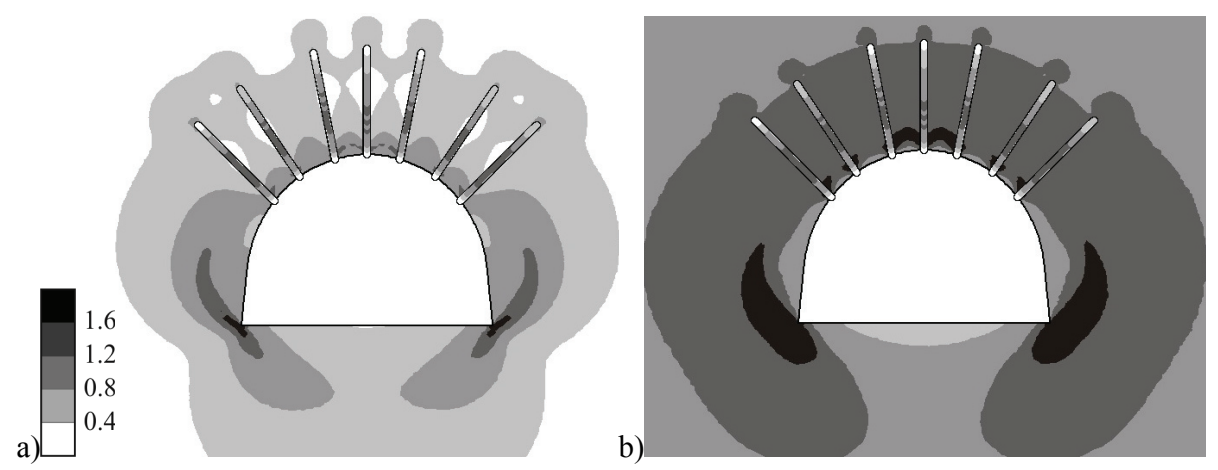

Fig. 8. The distribution of the geomechanical parameters values in the border rocks and roof bolts, the intermediate scheme of the support setting: $\mathrm{a}-Q ; \mathrm{b}-S_{\max }$. 


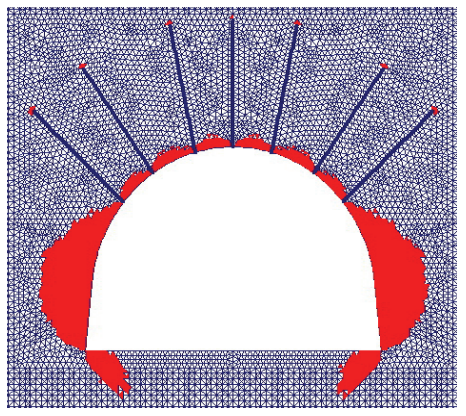

Fig. 9. The zone of inelastic deformations, intermediate scheme of the support setting.

At the third stage, the formation of a complete roof bolting and frame structure is being completed. The additional roof bolts are set into the sides of mine working (near the bottom roof bolts B1-B4 in Figure 3), strengthening the bearings for the roof bolting and rock overlapping in the roof. The frames are also being set if they have not yet been installed at the previous stage. The distributions of the stresses field parameters are shown in Figures 10, 11 after the face recedes at a distance of $60 \mathrm{~m}$, as well as the setting of bottom roof bolts and a frame.
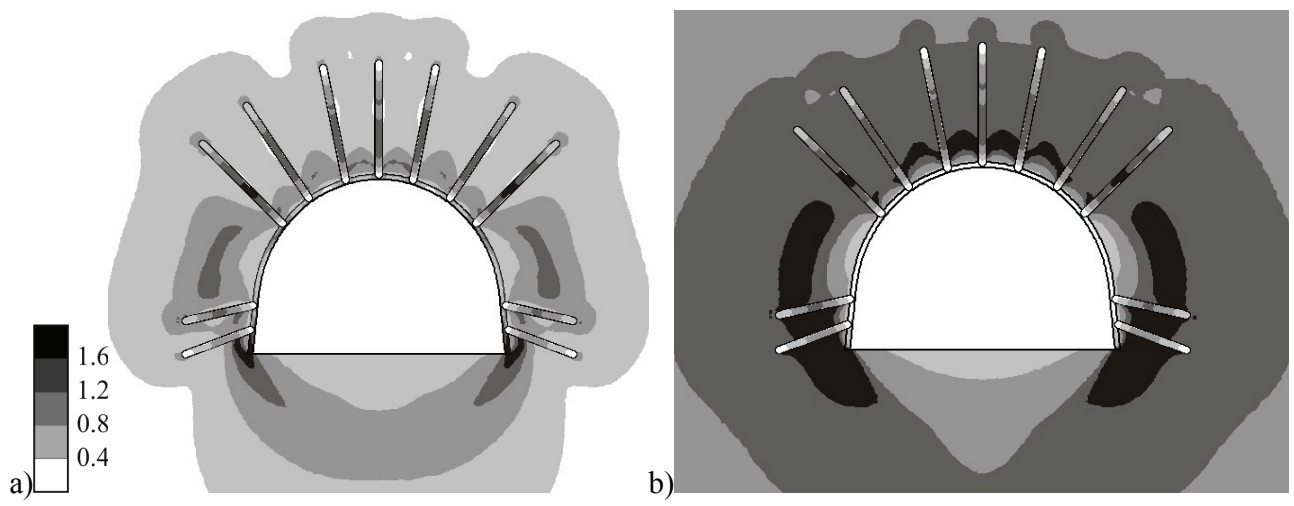

Fig. 10. The distribution of the geomechanical parameters values in the border rocks and roof bolts, the complete scheme of the support setting: $\mathrm{a}-Q ; \mathrm{b}-S_{\max }$.

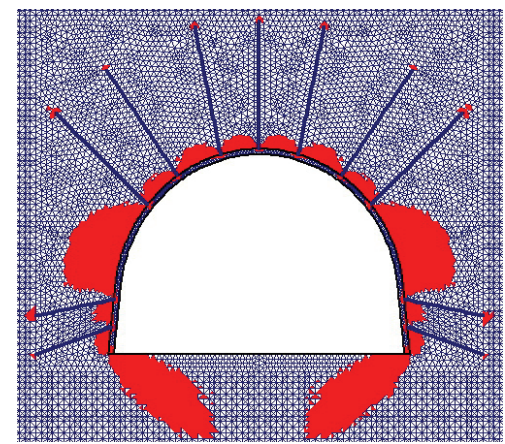

Fig. 11. The zone of inelastic deformations, the complete scheme of the support setting.

With the setting of the roof bolts B1-B4, the process of pressing-out the coal in the sides of mine working is blocked, the formation of fractures is almost not developed. The values of the averaged geomechanical parameters in these zones are changed: the application of side roof bolts lowers the value of $Q$ parameter and significantly increases the value of the 
minimum component of the principal stresses tensor. This indicates that the possibility of rocks destruction in the sides of mine working, which serve as a bearing for the roof bolting and rock overlapping in the roof, decreases.

The performed studies have shown that there is a possibility to effectively distribute in time the order of setting the roof bolting and frame support, while maintaining mine working in a stable operating condition and ensuring the necessary rate of its development. Such a technological approach makes it possible to successfully prepare the stope works area in the conditions of intensified coal mining.

\section{Conclusions}

The modification of the technology developed at the Institute for bearing and roof bolt supporting of mine workings in the conditions of increasing the coal mining intensity has been made. The technological schemes have been developed for the phased construction of roof bolting and frame support, which allows to:

- postpone temporarily the setting of frames in the mine working face;

- reduce the time and labour intensity for covering with a grid of the mine working arch and setting the roof bolts;

- increase the degree of rocks strengthening;

- increase the safety of mining operations;

- increase the rate of mining operations using the existing equipment.

The changes have been studied in the stress state of the border massif during the elements staged construction of roof bolting and frame support. The performed studies have shown the possibility to effectively distribute in time the order of setting the roof bolting and frame support, while maintaining mine working in a stable operating condition. The technology of phased construction of roof bolting and frame support ensures the maintaining of the stable state of rocks. In addition, the time between the extraction of the coal-rock mass and the setting of the primary support, as well as the distance between the face and the first row of roof bolts are reduced to a minimum. In this case, the border rocks of the non-fastened part of the roof and sides of mine working do not have time to unload from the rock pressure and their integrity will be maintained to the full.

The proposed technology has been tested in the conditions of the Pavlogradska Mine and Stepna Mine, where the setting of frame supports and side roof bolts has been made with a certain lagging. The new technological approach has made it possible to ensure the rate of preparatory mine workings development, which is necessary for the stope works performance in the conditions of intensified coal mining.

\section{References}

1. System of providing reliable and safe functioning of roof bolting mine workings. General technical requirements. (2014). Kyiv: Ministry of Energy and Coal Mining of Ukraine

2. Bulat, A.F., Vinogradov, V.V. (2002). Oporno-ankernoe kreplenie gornyih vyirabotok ugolnyih shaht. Dnepropetrovsk: Vilpo

3. Bulat, A.F., Popovych, I.M., Vivcharenko, O.V., Krukovskyi, O.P. (2014). Tekhnolohiia ankernoho kriplennia hirnychykh vyrobok na shakhtakh Ukrainy: stan i perspektyvy. Uhol Ukrayny, 2, 3-7

4. O.P. Krukovskyi. Application of roof bolting support in the Ukrainian mines, Proceedings of the 25th World Mining Congress (2018)

5. Yakovlev, D.V., Magdych, V.I., Egorov, A.P., Osminin, D.V., Markov, A.S. (2014). 
Prospects of development and implementation of stage-by-stage mine working roof bolting flow charts in Kuzbass mines. Ugol, 10, 40-44

6. Demin, V.F., Yavorskiy, V.V., Demina, T.V., Chvanova, A.O. (2017). Substantiation of technological schemes of anchoring when conducting mining. International journal of applied and fundamental research, 6, 27-32

7. Vynohradov, V.V., Krukovskyi, O.P. (2010). Oporno-ankerne kriplennia hirnychykh vyrobok vuhilnykh shakht Ukrainy. Geotehnicheskaya mehanika [Geo-Technical Mechanics], 88, 170-179

8. Krukovskyi, A.P., Krukovskaia, V.V., Khvorostian V.A. (2013). Tekhnolohyia opornoankernoho kreplenyia hornykh vyrabotok uholnykh shakht Ukrayny. Uhol Ukrayny, 2, 13-16

9. V.M. Nguyen, Q.P. Nguyen. Analytical solution for estimating the stand-up time of the rock mass surrounding tunnel, Tunnelling and Underground Space Technology, 47 (2015)

10. V.M. Seryakov. Calculating stress state of support and sidewall rocks in stagewise face drivage in long excavations, Journal of Mining Sciences, 51 (2015)

11. O.C. Zienkiewicz, R.L. Taylor, J.Z. Zhu. The Finite Element Method: Its Basis and Fundamentals (2013)

12. Krukovskyi, O.P. (2011). Modelling changes of stress-strain state of solid edge during the distance of working face of mine workings. Problemy obchysliuvalnoi mekhaniky $i$ mitsnosti konstruktsii [Problems of computational mechanics and strength of structures], $17,175-181$

13. R. de Borst, M.A. Crisfield, J.J.C. Remmers, C.V. Verhoosel. Non-linear finite element analysis of solids and structures (2012)

14. Kovalevska, I., Symanovych, G., Fomychov, V. (2013). Research of stress-strain state of cracked coal-containing massif near-the-working area using finite elements technique, Mining of Mineral Deposits, 159-163 